\author{
Putayeva E., \\ Teacher, Ph.D. student, \\ Department of Linguoculturology \\ Azerbaijan University of Languages
}

\title{
SEMANTIC FEATURES OF LOANWORDS FROM NATIVE AMERICAN LANGUAGES IN AMERICAN ENGLISH
}

\begin{abstract}
Summary. Any discussion of the impact of languages on American English must also observe that American Indians and languages they spoke had a direct consequence of the settlement of the New World by the European nations. Among the languages that have influenced the formation of English in North America, the influence of Indian languages is indisputable. One of the functions of researches about the Native American traditions has always been to consolidate the tribes and to donate it with an incessancy and communality. Ethnic identity can be maintained as an active element of communal life even within the larger "group of people i.e. nation". Native Americans were seen as beyond assimilation, since their ethnicity was quite divertive from the traditions of the Northern American culture. As a result of the research, it became clear that most of the words from the languages of these tribes were introduced to American English in the $17^{\text {th }}$ century and some in the $18^{\text {th }}$ and $19^{\text {th }}$ centuries. A number of loanwords of the Indian tribes expressing their way of living, their religious rituals and attitudes, their unique instruments, weapons, and other objects used by them were considerable. New environment for living, main natural and public circumstances helped to enrich the word stock of the English language due to the assimilation of borrowings from languages of Native Americans. Significant contribution to American English was the great amount of words naming animals, fruit, meals, birds, fish, trees and others; at the same time names of states, rivers and lakes, cities and towns.
\end{abstract}

Key words: American English, loanwords or borrowings, assimilation, Native Americans, indigenous tribes.

Introduction. By the time European representatives arrived in North America, local Aborigines had already been living in these lands for many years. Archaeological researches proved that the indigenous tribes settled in these areas approximately 30,000 years ago, before Europeans got acquainted with the new continent. Indigenous tribes who have lost most of their lands at the end of the occupation comprise currently only $2 \%$ of the total US population. However, in the meantime, a lot of words used in the language of indigenous tribes have been introduced into the American English and are contemporarily included in the dictionaries. New living conditions, including natural and social ones have enriched American English by loaning new words. Unknown rules for living, social situation, and even natural environment highly influenced the process of gaining new borrowings. Eventually, a number of words denoting everyday way of living and natural need entered $\mathrm{AE}$ in the early periods of correlation. e.g. tomahawk, mocassin, curare, pemmican, etc.

The main way of cooperation of native tribes and newcomers was a trading process. e.g. a new dialect was formed where tribes from Chinuck origin lived. As a result of this trade relations new words and word expressions found their way to the AE. Undoubtedly, these words which describe different traditions of native tribes, some notions denoting substances of everyday usage are used even nowadays. The debate of the effect on American English absolutely requires the necessity of using right terms that refer to the peoples of America. Indigenous peoples of Western Hemisphere are called in various ways: Native Americans, American Indians, Indians, and Amerindians. Words from Native Americans' clans often found their way into American English by means of Spanish and Portuguese, the language of Aztecs, who were the most advanced ones.

Different spheres of everyday living in the U.S. represented by the borrowings show that the great number of loanwords are related to Native American culture and civilization. It was considered to be right to loan the Native American word than imagine a new one. For example, igloo, an Algonquian term for a house or tent, appears in English as early as 1628 .

Since the 70-80s of the last century, researches on American Indian languages have been at the great height of the development of fieldwork techniques for investigating semantic characteristics of the languages. Though this article presents techniques which are intended to be applicable to fieldwork on any language, it was betrothed all of its examples which were taken from American languages. Our approach relies on accumulating different parallel strata of various semantic fields of borrowings. The first phase relies on defining various words of Native American origin to be incorporated. The second phase refers to determining various semantic groups of loanwords. Consequently, the final phase includes the interpretation of results as well as the contrastive analysis of the data collobarated through the research. The findings are subject to qualitative analysis, comparisons and interpretations, as well as observational investigation of the given data.

The purpose of the article was to examine the words of indigenous origin, that is the words taken from the languages of Indian tribes which were loaned into American English; to identify their role in the enrichment of the vocabulary of the given language, and to define the semantic groups of those words obtained from the languages of the Native American tribes.

Relevance of the article. As time passes any language interacts with other languages, and is directly or indirectly affected by these languages, and consequently the vocabulary of the language is enriched by loaning of new words from various languages. These effects are both of diachronic and synchronic aspects. When examining the influence of Indigenous tribes on English, as well as on American English, it may be of particular importance to determine which semantic groups these words generally refer to. 
Background study. Loanwords from the Native American languages occurred in English from a very early period. Generally speaking, about one-half of all the Native American borrowings, currently used in the language, became a part of it during the first part of the $17^{\text {th }}$ century; the other half may be divided about equally between the $18^{\text {th }}$ and $19^{\text {th }}$ century borrowings. As most languages prefer to re-form loanwords in their own general structure, it was natural that these words could have been changed in everdyday contact [1, p. 191].

Most English speakers could easily distinguish and label words like tomahawk, moccasin, or tepee as having Amerindian origins (from Virginia, Algonquian, and other languages), but indigenous American languages have given English many other words which have now become so naturalized that their basis often become fully altered. In fact, nearly half of the names of the US states (including Arizona, Connecticut, Kentucky, and Missouri, to indicate only a few of them) are derived basically from Amerindian words. Even some words which appear to be thoroughly English have concealed Amerindian roots: e.g. woodchuck, which looks like a typical English compound incorporating the word wood, is actually a folk-etymological simplification of an Algonquian word. As well as, sockeye, referring to the distinctive salmon of the Pacific Northwest, reinterprets a Salish word suk-kegh. The English were newcomers to the Americas, but they collided not only indigenous peoples, but also other European colonists who had already engaged regional words into their own word-stock. Many words from North American languages made their way into English through the mediator of another colonial language. Coyote and mesquite also entered English through Mexican Spanish, originated in Nahuatl and supposed to be the origin of chocolate. Caribou and toboggan are of Mikmag origin and came to English through Canadian French. Any analysis of the influence of Amerindian languages on English should also contemplate its use: the misplacement and devolition of American Indian peoples and the languages they spoke which was a direct repercussion of the continent's settlement by speakers of English and other European languages. In the centuries since European colonization, many of the indigenous languages of North America have been disapproved, or disgraded to a tiny, aging population of native speakers. Under present circumstances, the majority of indigenous languages still used in the United States have partially changed, and many communities are now seeking to reactivate their linguistic inheritance [2, p. 462-463].

Discussion. The Native Americans have influenced many spheres of the American way of life, from law and government to art and music. The Indians served as guides in the early exploration of this hemisphere. Their trails became the roads and railroads over which the settlers advanced in search of new homes. The Indians have also been immortalized in song, painting, art and sculpture. Symbols such as the totem pole, thunderbird, sun and tepees, as well as the Indian's love for color have had a prominent place in developing modern design. A great deal of Indian words have become a part of the English language. Some sample words are: barbecue, cannibal, caribou, chipmunk, chocolate, cougar, hammock, hurricane, mahogany, moose, opossum, potato, skunk, squash, toboggan and woodchuck. We are also aware the names of various games and activities developed by Indians: cat's cradle and bull roar, canoeing, snowshoeing, lacrosse, tobogganing, etc. [3, p. 2-4]. Indians also have contributed a great deal to farming methods. The white settlers in colonial America could not have survived if they had not gained Indian farming methods.

\section{State names}

As well as, many places in the United States have names of Indian origin. Approximately half of the U.S. states have Indian names. Here is given the list of the names of states which are of Indian derivation.

Alabama - the name of Muskogean tribe, meaning "those who use lands for agricultural aims". Alaska - word of Aleut origin meaning "great land" or "that the sea breaks against". Arizona from the Papago word, Airzonac, which probably means "small springs". Arkansas - From Akansea, a tribe whose name means "downstream people". Chicago - Algonquian for "garlic field" or "skunk place". Connecticut - meaning "river whose water is driven by tides or winds". Dakota - tribal name of the Sioux meaning "Allies". Illinois - meaning the name of Algonquian tribes. Iowa from an Indian word which expresses the meaning "the Beautiful Land". Kentucky - supposed to be derived from the word meaning "Field". Manhattan - Lenape, believed to mean "large island in water". Massachusetts - an Algonquian tribe which means "at the Great Hill". Michigan - from the Indian word "Michigamea, meaning "Great Water". Minnesota - A Dakota word expressing "Whitish water". Mississippi - Algonquian word "misi" meaning "Great," and "sipi," meaning "water". Missouri - from the tribe's name meaning "Great Muddy," which refers to the river. Nebraska from an Oto word meaning "Broad Water". New Mexico - name of an old Aztec god, called "Meritili". Niagara - named after an Iroquoian town, "Ongiaahra". Ohio - from an Iroquoian word which means "big river". Oklahoma - from Choctaw words meaning "red men" [4]. These are only few examples of the great amount of state names, as well as toponyms of indigenous origin.

\section{Names expressing lifestyle}

Most of the borrowings had to do with the way the Indians lived their lives, their habits, their customs and traditions, their tools. The majority of the acquisitions, dating before the $17^{\text {th }}$ century, came from the languages of Indian tribes. The main reason for this was the need for expressions that were not familiar to European nations. They needed not only the words aborigines used which were especially related to flora and fauna, but also there was need for the use of words related to their everyday life, mythology, customs and traditions. Because the reflection of these concepts in the language could have been achieved by assimilating the relevant aboriginal words in English. Concepts and objects related to the unique spiritual and material culture of the Aborigines were not familiar to the newcomers. When we investigate the semantic features of those words, we see that these words mainly cover the names of goods, means of transport, and tools associated with the lifestyles of indigenous peoples. For example: oamiac is a large boat made of animal skin; kayak - light boat; comiac - skiing; toboggan - sliding on the mountain; wangun - boat, crate for food; wigwam - tent, shelter, home; tomahawk - axe, cutting tool; wampum - money unit; coollamon - wooden containers for water retention; dilly - bags made of grass, etc. [5]. One cannot deny that all these words were fully or partially assimilated and adjusted to the phonetic system of American English. e.g. "wangum" was firstly used as atawangan, then atawan and finally wangun. The other example of this kind of assimilation is "wigwam" which was pronounced as wiwaum or wigiwam in its original language. "Currare" had a great evalution process of the following type: woorara - ooradi - urari - woorali - and finally obtained the form of its modern usage. 


\section{Names of settlements}

The vast majority of words derived from the languages of Indian tribes express the names of the settlements. For example: gunyah - home, hut; wurley - house, residence; humpy - a place to live, wigwam - home, small houses, living space; wickiup - coma; tepee - vigwam; igloo - a house made of snow and so on. Wigwam houses are made of woods, like an arched rectangle, not portable, but convenient to build. But igloos are built using whale bones instead of wooden pillars and are usually accommodated with snow to form a cupola.

\section{Names related to food and local cuisine}

The names of dishes and food also shifted from the languages of Indian tribes to American English, and gained a wide range of expressions to name the dishes that were characteristic to the cuisine of these tribes. Most of these words have been assimilated partially or thoroughly. Let's consider a few examples: tapioca - special flour, hickory - juice, pemmican - dried meat, hominy - crushed corn meal, succotash - babua fruit, hooch alcoholic beverage, etc.

Another example: squash - any of various fruits of plants of the gourd family widely cultivated as vegetables. Squash is a shortened form of what the Narragansett, an Algonquian-speaking tribe from Rhode Island called asquutasquash. And they described it as a cake, bread and "kind of Mellon". Though today considered a vegetable in cooking, the squash is a fruit even if it seems too starch-like to be in the same family. Let's give a deep explanation of some loanwords, their semantic and phonetic evalution. e.g. "tapioca" was firstly used as tapioca in the meaning of surviving, staying alive. Hickory took its modern form from powcohickora, later turned into pohickery and at last hickory in the meaning of fruit juice. Pemmican was taken from Cree tribe languages in the $18^{\text {th }}$ century and its original variant sounded like pimecan. The other interesting and irrelevant point of this borrowing is that its semantic modification even brought the meaning of "short, brief content" to the language.

\section{Words related to occupation}

As job-specific words for a highly developed society are not typical of American Aborigines, words are derived from their language to only those who operate in primitive societies. In these primitive societies, professions such as witchcraft and leaders were common. In these societies, monarchs, kings, and knights were replaced by tribal leaders, and as a result, Indian words were translated into English from that level of development. For example: sachem - head; cockarouse - boss, leader; pow-wow clergyman, judge; mugwump - senior leader; coradgee - wise man; squa - Indian woman; papoose - Indian child; gaucho - shepherd and others [1]. The word sachem found its way to the American English in the $17^{\text {th }}$ century and its counterpart had a form of sagamore in the meaning of political leader.

\section{Words related to myth and religion}

The ancient and rich mythological and religious traditions of the Indian tribes have found wide expression in their language. Naturally, a part of that lexical stratum was adopted as a result of the contacts of the English-speaking population. For example: manitou - spirit, God; corrobore - a bustling religious holiday; didgoridoo - a musical instrument used in religious ceremonies; bora - a religious ritual conducted by aborigines; borak - a religious holiday. While_speaking about phonetic assimilation of these loanwords it is also unavoidable to mention the process of changing of the following words: Manitou - from Manitu, corrobore - from corraboree, bora - from bur, borak - from buruk, etc.

\section{Methaphorical expressions}

Many factors played a great role in the formation of American English stylistically emotional lexicon. Extralinguistic factors including variety of the flora and fauna of the country, the way of living, different areas of culture and others played a significant role in this process. The enrichment of the American English style vocabulary has been made possible by transfering of new meanings to words and the usage of words from other languages. Currently, many territories, regions, rivers and lakes are still referred to in the language of these tribes. City names - Biloxi, Cheyenne, Miami, Montauk, Mobile, Natchez, Spokan, Wichita, Walla, Yuma, etc.; river and lake names - Erie, Ohio, Huron, Missouri, Michigan, Minnesota, etc.; mountain and desert names - Apalachee, Mohave, Shasta, Teton and others [6, p. 155].

The formation of a new lifestyle for North Americans is directly related to the new conditions that come here. Americans who wanted to adapt to new living conditions and had to learn a lot from the Native Indians and, as a result, formed customs and traditions that were appropriate to the economic conditions of the country. The same is true for other areas of agriculture, hunting and so on. Let's look at a few examples: squash - this type of vegetable, which is used as askutasquask, askoat, askuash, and means green, bald, unsweetened, has gained the meaning of pressure, smoothing, and now, in order to change the shape of something figurative is being used a lot. On the other hand, it is used to define the meaning of density and frequency.

The comparatively earlier acquisitions that we have encountered in the early $17^{\text {th }}$ century in the literature were Indian words, and were related to the indigenous peoples who lived in the area before the arrival of the English, who mainly spoke the languages of the Algonquian group. Many of these acquisitions have gradually disappeared, and some have been preserved until today. Many derived words from the Indian languages have been assimilated both phonetically and semantically. For example: Wigwam - even though it denotes tents - has continued to be used as a house later in the form of "wiwam". Currare is a harmful substance used to poison arrows, but has long been assimilated, causing the initial oorari, urari, woorali to change. Let us look at other examples: the word pemmican, in its original form, has altered the meaning of complementary thinking, in addition to the meaning of a particular type of meal. In the early years of American colonization, powwow, derived from the Indian language, was used to mean "clergyman, midwife, and magician". He then began to express the ceremonies where wizards performed dances in the feasts. Later, the pow-wow conference in America began to be used as a conference. The same is true of the word mugwump, which is derived from the Indian language. The word was formed as a result of the assimilation of the word meaning chief, chief executive, in the language of the Natik Indian tribe. The word "totem" was also used in Indian language to denote the primitive social structure of Aborigines. Totem is derived from the word totam, toodaim, odamam, ototetam in the language of the Algonquian tribe. Ote or otem in that language also means family, tribe. This word was also morphologically assimilated, giving rise to many words [3, p. 2-3].

The words taken from the Native Indians have formed a variety of phrases in English, creating new phraseological unities. Consider a few examples: 
Mug-wump is a word combination used to describe a person who can't vote. Although the original form was used as a chief executive, and was later used to refer to Democratic Republicans who support the Democratic Party, figuratively to be used as a mugwump. It is sometimes used to describe supporters who support one party or sometimes another party. The phrase "smoke the pipe of peace" means peace after a long conflict. The history of this expression goes back to the traditions of ancient Indian tribes, as the two rival tribes agreed to make peace and this expression began to work in the sense of peace. In another expression, the word tamahawk, which is an Indian word for axe, means to stop or start a war, conflict, or initiate war in "bury the tomahawk" or "to raise the tomahawk". Here, too, the conflict ended when tribes buried the axe they used as weapons; when the axe was dug out of the ground, it indicated that the conflict had already begun. As "to toboggan" means to slide down the mountain, the phrase "prices tobogganed" is used to express that the prices decreased suddenly and unexpectedly.

Sources of loanwords. Finally, let's take a look at a few Indian words that have contributed to the enrichment of American English. From Nahuatl: avocado - avocado (fruit), cacao - cocoa, chocolate - chocolate, tequila - tequila, tomato - tomato, etc. From Quechua: coca - drink, cocaine - drugs, guano - animal fertilizer, inca - king, lord, guide; gran chaco - hunting, catching; jerky meat duck, pampa - wide area, pisco - bird, puma - puma and so on. From Eskimo-Aleut languages: igloo - house, kayak - boat, muckluck - animal leather shoes, nanook - polar bear, etc. [7, p. 11].

Since the Nahuatl language of Indian tribes is of particular interest, we must speak in detail. One of the interesting facts is that these acquisitions did not go directly into English, but rather through other European nations, especially Spanish and French. Words derived from these languages can be classified according to the semantic domain they belong to, as well as the chronology of language acquisition. Haugen categorized Nahuatl's words into American English according to the following semantic groups: animal names, plant names, culinary concepts, herbal and psychotropic plants, religious and mythological concepts, cultural concepts and events, ethnological terms and language names, mineralogical concepts. words not included in the group. The author attempted to show the numerical expression of words belonging to each group of meaning and gave an approximate number of loanwords [8, p. 64-67]. In the category of culinary concepts, the author includes fruits and vegetables, as well as plants that can be eaten by humans, and words related to the process of their preparation. The vast majority of these words were also available in American English in the $17^{\text {th }}$ and $18^{\text {th }}$ centuries, and even in the middle of the 20th century. The category that creates the next semantic meaning group is the names of herbs and psychotropic plants, which include plant names that can have a positive or negative impact on people's health. Example: marijuana - marijuana, mescal - drink type, octane (octopus), peyote - mescaline (a type of cactus), sotol - spice grass, tepache - pineapple drink and so on. Most of these words were adopted in English in recent times, in the middle of the $19^{\text {th }}$ and early $20^{\text {th }}$ centuries. Although words that express religious and mythological concepts may not be used in everyday spoken language, they can be used to express the religious and mythological beliefs and ideas of the peoples of the United States. These words coincide with the end of the sixteenth century in the early stages of interaction between indigenous people and newcomers. For example: nagual - naval, mythological creature resembling animal body and shape, teocalli - temple, teopan - place of worship, Quetzalcoatl - the name of the God who worships and protects the lives of Nahuatl people.

Expressingculturalunderstanding and events ofpeople,D. Haugen also included household items, tools, clothing, and the names of concepts related to the functions of human life. For example: metate - small hand mills for coffee, petaca - tobacco bowls, jacal summer hats, slippers and tops. When looking at the chronology of words belonging to this group of words, the main reason why no words in the eighteenth century were included in the English language is that trade relations between peoples were very weak during the period mentioned. For example: coca - drink, cancha stadium, carp - tents, cocaine - drugs, guano - animal fertilizer, inca - king, lord, guide, chaco - hunting, catching, chacra - planting house, chino - dark sturdy fabric used for the construction of work clothes, uniforms, chullo - earrings, condor - raven, cura - priest, gaucho - orphan, lonely, jerky - finely chopped and sun-dried meat, lagniappe - add, Lima - the capital of the state of Peru, pampa - vast territory, pisco - bird, etc. [8, p. 66-72].

Conclusions. It was unavoidable that the U.S. population, who were in close contact with the tribes who spoke indigenous languages, accepted words that express certain concepts in English. For example: igloo - house, snake - friend, kayak - boat, muckluck - animal leather shoes, nanook - polar bear, etc. As can be seen from the examples, the words derived from these languages are the names of living places, household items, vehicles, and animal names that are common to these peoples.

At the end of the study, we come to the conclusion that American English has been enriched by word-for-word acquisitions and has formed its own dictionary. These extracts are seen as a prime example of the centuries-old historical ties and interactions of indigenous tribes and newcomers. When we look at the semantic characteristics of American English-speaking Indian languages, we see that the words expressing everyday life, plants and animals, toponyms, food and transport are surely predominant ones.

\section{References:}

1. Puri, V. Focus on Indian English. Published online: 26.07.2016.

2. Thomas, P., Salmons J. Contact and development of American English. Oxford : Blackwell, 2010. Pp. 454-477.

3. Petsko, E. Common English words from Native American languages. Mental Floss, 2018.

4. James, B. Barnes. States that were named by Native Americans. Published online: 15.10 .2014$.

5. Zappia, N. Native American History. Timeline Paper, 2013.

6. Потеряева Е.Ю. Америндские заимствованные этнонимы в американском варианте английского языка. Языкознание. 2009. № 12 (90). Ст. 154-158.

7. Campbell, L. American Indian Languages. Oxford University Press, 1997. $527 \mathrm{p}$

8. Jason, D. Haugen. Borrowed borrowings: Nahuatl loanwords in English. Lexis, 2009. Pp. 63-106.

9. Boas, F. Handbook of American Indian languages. Harvard University, 1911. $1091 \mathrm{p}$.

10. Greenberg, J.H. Classification of American Indian languages. Standford University Press, 1988.

11. John, B. King. Native American Indian Language and Culture in New York. The University of the State of New York, 2012. 44 p.

12. https://subscribe.ru/archive/job.lang.englishnews/201408/18130 519.htm 
Путаєва Е. Семантичні характеристики послідників природних американських мов

Анотація. Серед мов, які вплинули на формування англійської мови в Північній Америці, вплив індійських мов незаперечний. Головним фактом впливу цих індіанських племен $є$ співвідношення корінних американців у повсякденному житті. Одна 3 функцій досліджень про традиції корінних американців завжди полягала в тому, щоб об'єднати племена й обдаровувати їх безперервністю і спільністю. Етнічна ідентичність може підтримуватися як активний елемент суспільного життя навіть у рамках більш широкої «групи людей, тобто “націй”». Корінні американці вважалися за межами асиміляції, оскільки їх етнічна приналежність вельми відрізнялася від традицій північноамериканської культури. В результаті дослідження 3'ясувалося, що більшість слів мов цих племен була введена в американську англійську в XVII столітті, а деякі - в VIII і XIX століттях. Запозичені слова індіанських племен, які виражають їхнй спосіб життя, їхні релігійні ритуали і погляди, їхні унікальні інструменти, зброя та інші предмети, які вони вживали, були значними. Різні сфери повсякденного життя в США, представлені запозиченнями, показують, що велика кількість запозичених слів пов'язана з культурою і цивілізацією корінних американців. Нове середовище для життя, основні природні і суспільні обставини допомогли збагатити словниковий запас англійської мови шляхом асиміляції запозичень із мов корінних американців. Вважалося правильним запозичувати слова індіанців, ніж придумувати нові слова. Ці зразки розглядаються як яскравий приклад багатовікових історичних зв'язків і взаємодій корінних племен і новоприбулих. Коли ми розглядаємо семантичні характеристики американських/індіанських мов, ми бачимо, що слова, які виражають повсякденне життя, назви рослин і тварин, топоніми, назви держав, штатів, річок і озер, міст і селищ та ін., безумовно, домінують.

Ключові слова: американський варіант англійської мови, запозичені слова, асиміляція, корінні американці, індіанські племена. 